\title{
Activation of Peroxisome Proliferator-Activated Receptor-Gamma by Glitazones Reduces the Expression and Release of Monocyte Chemoattractant Protein-1 in Human Mesothelial Cells
}

\author{
Matthias Sauter, ${ }^{1}$ Kathrin Kastenmüller, ${ }^{1}$ Franziska Belling, ${ }^{1}$ Markus Wörnle, ${ }^{1}$ \\ Roland Ladurner, ${ }^{2}$ Thomas Mussack, ${ }^{2}$ and Thomas Sitter ${ }^{1}$ \\ ${ }^{1}$ Medizinische Poliklinik-Innenstadt, Klinikum der Universitaet Muenchen, Pettenkoferstr. 8a, 80336 Muenchen, Germany \\ ${ }^{2}$ Chirurgische Klinik-Innenstadt, Klinikum der Universitaet Muenchen, Nußbaumstr. 20, 80336 Muenchen, Germany \\ Correspondence should be addressed to Matthias Sauter, matthias.sauter@med.uni-muenchen.de
}

Received 9 August 2011; Accepted 30 October 2011

Academic Editor: Wolfgang Neuhofer

Copyright (C) 2012 Matthias Sauter et al. This is an open access article distributed under the Creative Commons Attribution License, which permits unrestricted use, distribution, and reproduction in any medium, provided the original work is properly cited.

\begin{abstract}
Human peritoneal mesothelial cells (MC) play an important role in inflammatory processes of the peritoneal cavity by producing various cytokines and chemokines, such as monocyte chemoattractant protein-1 (MCP-1). The present study was designed to assess the effect of the peroxisome proliferator-activated receptor-gamma- (PPAR $\gamma$-) activator rosiglitazone on the mesothelial MCP-1 expression and release. Primary cultures of MC were obtained from omental tissue. MCP-1 antigen concentrations were measured in the cell supernatant by ELISA and MCP-1 mRNA levels by real-time polymerase chain reaction. The presence of PPAR $\gamma$ on MC was assayed in a Western Blot analysis. MC constitutively express PPAR $\gamma$. Activation of this receptor via rosiglitazone $(0,1-10 \mu \mathrm{mol} / \mathrm{L})$ resulted in significantly reduced amounts of mesothelial MCP-1 release as well as MCP-1 mRNA. The use of the PPAR $\gamma$ inhibitor GW-9662 could completely prevent the rosiglitazone effects. Rosiglitazone was also effective in reducing TNF $\alpha$ induced enhanced secretion of MCP-1. Our findings indicate that glitazones are effective in reducing constitutive and TNF $\alpha$ stimulated mesothelial MCP-1 mRNA expression and release.
\end{abstract}

\section{Introduction}

Mesothelial cells (MC), which form the innermost monolayer of the peritoneal cavity, are critical in morphological and functional alterations of the peritoneal membrane in patients who undergo peritoneal dialysis (PD). They are a major source of intraperitoneal monocyte chemoattractant protein-1 (MCP-1) which is a chemokine that has been reported to play a key role in the recruitment of monocytes toward the peritoneal cavity [1]. Monocytes in turn contribute to peritoneal fibrosis by producing various cytokines and growth factors [2] that induce cell proliferation and extracellular matrix production in mesothelial cells and fibroblasts $[3,4]$.

Thiazolidinediones (TZD) are a novel group of antidiabetic agents that act via the activation of peroxisome proliferator-activated receptor-gamma (PPAR- $\gamma$ ), a nuclear hormone receptor. PPAR- $\gamma$ regulates a variety of metabolic pathways as a transcription factor [5]. Therefore, TZD like rosiglitazone are not only capable of increasing the insulin sensitivity in peripheral organs (as e.g., adipose tissue) and thus lowering blood glucose levels in diabetic patients; they also possess anti-inflammatory capacities in certain circumstances as they decrease the expression of inflammatory proteins like iNOS and MMP9 in macrophages $[6,7]$. A reduced expression of MCP-1 due to TZD treatment has been shown for diverse cell types as, for example, lung epithelial [8], endothelial [9], and mesangial cells [10]. In this context, the present study was designed to investigate the presence of PPAR- $\gamma$ on human peritoneal MC and to characterize the effect of PPAR- $\gamma$ activation by TZD on mesothelial MCP-1 mRNA transcription and release. 


\section{Materials and Methods}

2.1. Materials. Medium M199 and newborn calf serum were obtained from Gibco BRL (Eggenstein, Germany); tissueculture plates came from Costar (Cambridge, Massachusetts, USA). Human serum was prepared from freshly collected blood of healthy donors and stored at $-20^{\circ} \mathrm{C}$. Fibronectin from human serum, trypsin, and $\mathrm{TNF} \alpha$ were purchased from Boehringer (Mannheim, Germany), collagenase type II from Worthington (Freehold, NY, USA).

Monoclonal antibodies against cytokeratins 8 and 18 as well as vimentin were a gift from Dr. G. van Muijen (University of Nijmegen, The Netherlands). Antibody against PPAR$\gamma$ was from Santa Cruz Biotechnology (Santa Cruz, California, USA). MTT was from Sigma-Aldrich (St. Louis, MO, USA). Rosiglitazone was from Molekula (Nienburg/Weser, Germany), and GW-9662 was purchased from Cayman chemical (Ann Arbor, Michigan, USA).

2.2. Cell Culture Experiments. MC were isolated from the omental tissue of consenting patients undergoing elective surgery, as described previously [11]. The patients were free from peritonitis or peritoneal carcinosis. Cells were grown in fibronectin-coated dishes in M199 medium supplemented with $25 \mathrm{mmol} / \mathrm{L}$ HEPES (pH 7.3), 2 mmol/L glutamine, 10\% $(\mathrm{v} / \mathrm{v})$ human serum and $10 \%(\mathrm{v} / \mathrm{v})$ newborn calf serum (heat inactivated), penicillin $(100 \mathrm{IU} / \mathrm{mL})$, and streptomycin $(100 \mu \mathrm{g} / \mathrm{mL})$ at $37^{\circ} \mathrm{C}$ under $5 \% \mathrm{CO}^{2} / 95 \%$ air atmosphere. The medium was replaced every 2 to 3 days. Subcultures were obtained by trypsin/EDTA treatment at a split ratio of $1: 3$. The cells were purely MC, as assessed by their uniform cobblestone appearance at confluence, by the absence of von Willebrand factor, and by their uniform positive staining for cytokeratins 8 and 18 as well as for vimentin. For the experiments, confluent cultures were used at the second or third passage, and cells were refed with $2 \%$ human serum 24 hours before the experiment. Conditioned media were obtained by incubating cells in $2 \mathrm{~cm}^{2}$ dishes at $37^{\circ} \mathrm{C}$ with $0.5 \mathrm{~mL}$ serumfree M199 containing the appropriate concentration of the test compound. Serum-free medium M199 served as a control. In coincubation experiments with $\mathrm{TNF} \alpha$, cells were preincubated for 24 hours with rosiglitazone, and then TNF $\alpha$ was added. In experiments using a PPAR- $\gamma$ blocker, cells were preincubated with GW-9662 for 24 hours. Supernatants were centrifuged 5 minutes at $2000 \times$ g to remove cells and cellular debris, and the samples were frozen at $-20^{\circ} \mathrm{C}$ until use. All experiments were done with cells from 3 to 6 individual donors and were measured in triplicate.

2.3. Western Blot Analysis. Cultured human mesothelial cells were harvested with lysis buffer (50 mM Tris-HCl pH7.4, 1\% Nonidet P-40, $0.25 \%$ sodium deoxycholate, $150 \mathrm{mM} \mathrm{NaCl}$, $1 \mathrm{mMEGTA}$, and $1 \mathrm{mM} \mathrm{Na3VO} 4$, Complete Protease Inhibitor Cocktail (Roche, Mannheim, Germany)). Extracted proteins were boiled in loading buffer for $30 \mathrm{~min}$, resolved by $8 \%$ SDS-PAGE under reducing conditions, and transferred to an Immobilon-P membrane (Millipore, Eschborn, Germany). The membrane was blocked with 3\% skim milk, incubated in a $1: 1000$ dilution of a rabbit polyclonal IgGantibody against human PPAR $\gamma-1$ (SC-7196, Santa Cruz Biotechnology, Heidelberg, Germany) over night, and rinsed with PBS containing $0.1 \%$ Tween 20 . Immune complexes were visualized using enhanced chemoluminescence (ECL, Amersham Biosciences, Freiburg, Germany). Human breast carcinoma cell lysate protein extract served as positive control for PPAR $\gamma$-1 detection.

2.4. MTT Assay. Human mesothelial cells $\left(30 \times 10^{3} / 100 \mu \mathrm{L}\right.$ medium) were cultured in 96-well microtiter plates for $24 \mathrm{~h}$ under standard conditions to yield firmly attached and stably growing cells. After discarding supernatants, $50 \mu \mathrm{L}$ of medium M199 containing rosiglitazone in concentrations of 1 and $10 \mu \mathrm{g} / \mathrm{L}$ or medium M199 as a control was added to the cells and incubated for $48 \mathrm{~h}$. Then $50 \mu \mathrm{L}$ of a $1 \mathrm{mg} / \mathrm{mL}$ solution of (3,5-Dimethylthiazol-2-yl]-2,5-diphenyl-tetrazolium bromide) MTT (SIGMA-ALDRICH, Taufkirchen, Germany no. M2128) was added. After $3 \mathrm{~h}$ incubation at $37^{\circ} \mathrm{C}$, formazan crystals were dissolved by addition of $100 \mu \mathrm{L}$ isopropanol and $0.04 \mathrm{~N} \mathrm{HCl}$. Absorbance was then measured at $590 \mathrm{~nm}$ using a GENios plus TECAN ELISA reader. For each experiment at least 6 wells were analyzed per experimental condition.

2.5. MCP-1 Assay. MCP-1 antigen levels $\left[\mathrm{pg} / 10^{5}\right.$ cells] were measured by Quantikine human MCP-1 immunoassay from R\&D Systems (Minneapolis, MN, USA). Diluted aliquots of the cell supernatants were assayed without prior purification.

2.6. RNA Isolation and Real-Time Quantitative RT-PCR. Total RNA was extracted from cells using silica gel columns (RNeasy, Qiagen, Hilden, Germany). $2 \mu \mathrm{g}$ of isolated total RNA underwent random hexamer-primed reverse transcription for one hour at $42^{\circ} \mathrm{C}$ using a modified Molony murine leukaemia virus (MMLV) reverse transcriptase (Superscript, Life Technologies, Karlsruhe, Germany). Real-time quantitative reverse transcription-polymerase chain reaction (RTPCR) was performed on a Taq-Man ABI 7700 Sequence Detection System (PE Biosystems, Weiterstadt, Germany) using heat-activated TaqDNA polymerase (Amplitaq Gold, Applied Biosystems, Darmstadt, Germany). Thermal cycler conditions contained holds for two minutes at $50^{\circ} \mathrm{C}$ and ten minutes at $95^{\circ} \mathrm{C}$, followed by 40 cycles of 15 seconds at $95^{\circ} \mathrm{C}$ and one minute at $60^{\circ} \mathrm{C}$. Message expression was calculated following the $\Delta \Delta \mathrm{Ct}$ procedure [12]. Glyceraldehyde3 -phosphate dehydrogenase (GAPDH) and $18 \mathrm{~S}$ ribosomal RNA (rRNA) served as the reference housekeeping gene. Controls consisting of $\mathrm{H}_{2} \mathrm{O}$ or samples that were not reverse transcribed were negative for the target and reference. Sequences with following gene bank accession numbers served for the design of the predeveloped Taq Man assay reagents (PDAR) or primers and probe, purchased from Applied Biosystems (Darmstadt, Germany): X14768 (human MCP-1/CCL2) M33197 (human GAPDH) and X03205.1 (human18s-rRNA). 


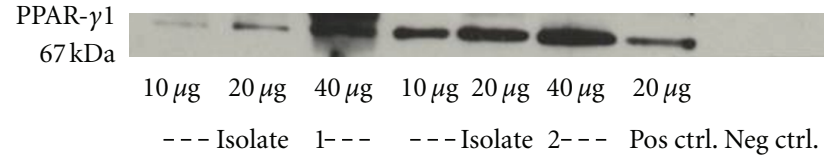

Figure 1: Western Blot analysis of PPAR $\gamma$-1 in two different isolates o unstimulated mesothelial cells. Total protein was extracted from unstimulated peritoneal mesothelial cells or human breast carcinoma cells (positive control) and were analysed using the Western Blot technique. The amount of total protein loaded is indicated. Pos. ctrl: positive control; neg. ctrl: negative control.

2.7. Statistical Analysis of the Data. Data are given as mean \pm SD. Statistical analysis was performed using the ANOVA analysis. A $P$ value $<0.05$ was considered to indicate statistically differences.

\section{Results}

3.1. Detection of Constitutive PPAR- $\gamma$ Expression in MC. We evaluated the presence of PPAR- $\gamma 1$ on human MC via Western Blot. Analysis of the extracted total protein of unstimulated MC showed a single band at $67 \mathrm{kDa}$ as has been described for PPAR- $\gamma 1$ and was comparable to the recommended positive control (protein from human breast carcinoma cells) (Figure 1).

3.2. Effect of Rosiglitazone on the Secretion of MCP-1 in Unstimulated MC. Confluent unstimulated MC were incubated with increasing concentrations of rosiglitazone (0.1$10 \mu \mathrm{mol} / \mathrm{L})$ for 48 hours. This resulted in a concentration-dependent decrease of MCP-1 protein levels in the cell culture supernatants. Rosiglitazone treatment reached statistical significancy at each employed concentration: A concentration of $0.1 \mu \mathrm{mol} / \mathrm{L}$ reduced the MCP-1 level to $13200 \mathrm{pg} / 10^{5}$ cells versus control $18200 \mathrm{pg} / 10^{5}$ cells $(P=$ $0.013)$ whereas a concentration of $1 \mu \mathrm{mol} / \mathrm{L}$ reduced MCP-1 levels to $12700 \mathrm{pg} / 10^{5}$ cells $(P=0.001)$ and a concentration of $10 \mu \mathrm{mol} / \mathrm{L}$ to $9400 \mathrm{pg} / 10^{5}$ cells $(P<0.001)$ (Figure $2(\mathrm{a})$ ). Rosiglitazone treatment in the shown concentrations did not effect cell viability as assessed in trypan blue staining or cell proliferation as assessed in an MTT assay (Figure 3).

3.3. Effect of Rosiglitazone on the MCP-1 mRNA Levels in Unstimulated MC. The incubation of MC with $10 \mu \mathrm{mol} / \mathrm{L}$ rosiglitazone resulted in a marked decrease of MCP-1 mRNA after a 4 hours' dwell time (0.09 versus 1$)$ (Figure 2(b)). A longer incubation time ( 8 hours) and the use of another housekeeping gene (GAPDH) resulted in comparable findings (data not shown).

3.4. Impact of $P P A R-\gamma$ Inhibition. In order to investigate whether the effect of TZD on the mesothelial MCP-1 release is dependent on the TZD property to activate PPAR- $\gamma$, MC were preincubated with the PPAR- $\gamma$ inhibitor GW-9662 ( $10 \mu \mathrm{mol} / \mathrm{L})$ or control media for 24 hours. Afterwards, cells were incubated with control media, rosiglitazone $10 \mu \mathrm{mol} / \mathrm{l}$,
GW-9662 $10 \mu \mathrm{mol} / \mathrm{L}$, or the combination of GW-9662 and rosiglitazone for 8 hours. In accordance with longer incubation times (Figure 2), rosiglitazone treatment led to a significant decrease in MCP-1 protein $\left(1700 \mathrm{pg} / 10^{5}\right.$ cells versus control: $2660 \mathrm{pg} / 10^{5}$ cells; $\left.P=0.028\right)$. GW-9662 did not have an effect on MCP-1 secretion and resulted in similar MCP-1 protein levels compared to control. The blocking of PPAR- $\gamma$ by administration of GW-9662 before a rosiglitazone application could completely prevent the rosiglitazone-induced attenuation in MCP-1 release $\left(2870 \mathrm{pg} / 10^{5}\right.$ cells versus $1700 \mathrm{pg} / 10^{5}$ cells; $P=0.039$ ) (Figure $4(\mathrm{a})$ ).

Corresponding results could be found on the transcriptional level: whilst rosiglitazone markedly reduced MCP1 mRNA levels ( 0.28 versus 1$)$, PPAR- $\gamma$ blockade by GW9662 resulted in considerably higher MCP-1 mRNA levels (0.62). GW-9662 alone had no effect on the MC MCP-1 mRNA production, as the administration resulted in a MCP1 mRNA level comparable to the control (0.86) (Figure 4(b)).

3.5. Effect of Rosiglitazone on TNF $\alpha$-Induced Enhanced Mesothelial MCP-1 Release. The incubation of MC with TNF $\alpha$ $(100 \mathrm{U} / \mathrm{mL})$ resulted in a drastic increase in mesothelial MCP-1 secretion $\left(67500 \mathrm{pg} / 10^{5}\right.$ cells versus control $4000 \mathrm{pg} / 10^{5}$ cells). Prior incubation with rosiglitazone $10 \mu \mathrm{mol} / \mathrm{L}$ and subsequent coincubation resulted in a onethird reduction in mesothelial MCP-1 levels $\left(43000 \mathrm{pg} / 10^{5}\right.$ cells versus $67500 \mathrm{pg} / 10^{5}$ cells) (Figure 5).

\section{Discussion}

MC are supposed to be critical in the pathogenesis of complications following PD treatment. By producing profibrotic $[13,14]$ and neoangiogenetic factors [15], they contribute to peritoneal fibrosis. In addition, $\mathrm{MC}$ are a major source of intraperitoneal MCP-1 and thus account for the recruitment of monocytes toward the peritoneal cavity [1]. Apart from an inflammatory reaction, this invasion contributes to peritoneal fibrosis by producing various cytokines and growth factors [2]. MCP-1 can be found in markedly elevated concentration in the dialysate of PD patients during and after episodes of peritonitis $[16,17]$. IL- $1 \beta, \operatorname{IFN} \gamma$, and TNF $\alpha$ as well as high glucose concentrations (due to high osmolality and the polyol pathway) are found to increase the mesothelial MCP-1 synthesis rate $[18,19]$. TZD are activators of PPAR- $\gamma$. This receptor is a member of the nuclear receptor family that includes 48 human transcription factors regulated by direct binding of steroid and thyroid hormones, vitamins, lipid metabolites, and xenobiotics [20]. By differential promotor usage and splicing two isoforms are generated: PPAR- $\gamma 1$ which can be found on a variety of cell types and PPAR- $\gamma 2$, which has an additional 30 amino acids at its N-terminal end and is expressed specifically in adipocytes [21]. We could now demonstrate the constitutive expression of PPAR- $\gamma 1$ on human MC. In PD patients, there are some experiences with TZD: Lin et al. described that rosiglitazone improved glucose metabolism in nondiabetic uremic patients on CAPD [22], and Wong et al. found reduced insulin requirement and C-reactive protein levels in 


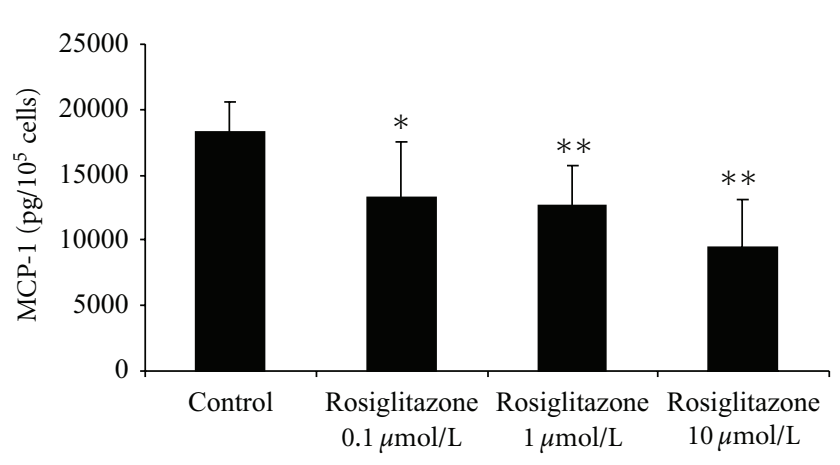

(a)

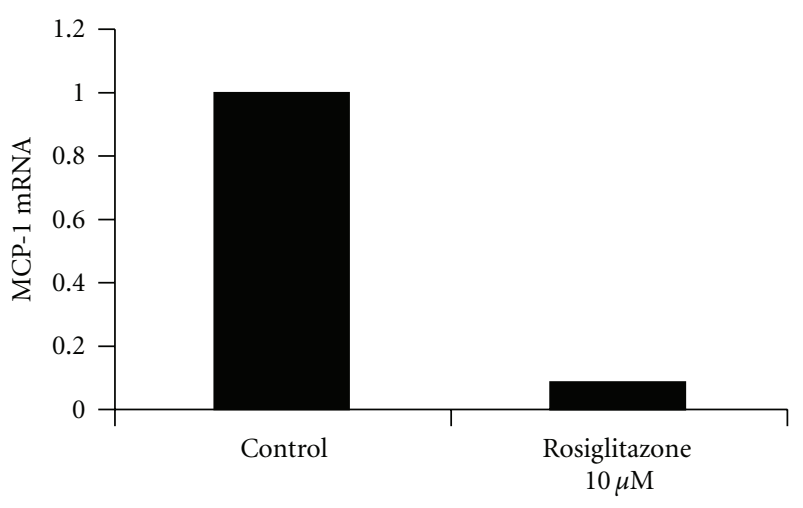

(b)

FIgure 2: (a) Effect of rosiglitazone on mesothelial MCP-1 release. MC were stimulated with rosiglitazone in the given concentrations for 48 hours. MCP-1 antigen was measured in the cell culture supernatants using ELISA technique. ${ }^{*}$ indicates a $P$ value $<0.05$; ${ }^{*}$ indicates a $P$ value $<0.01(n=6)$. (b) Effect of rosiglitazone on mesothelial MCP-1 mRNA levels. MC were incubated with rosiglitazone $10 \mu \mathrm{M}$ for 4 hours. Total RNA was extracted and analysed via RT-PCR. MCP-1 mRNA levels were adjusted to the housekeeper rRNA and are expressed as relative to the control. The figure is a representative of three independent experiments.

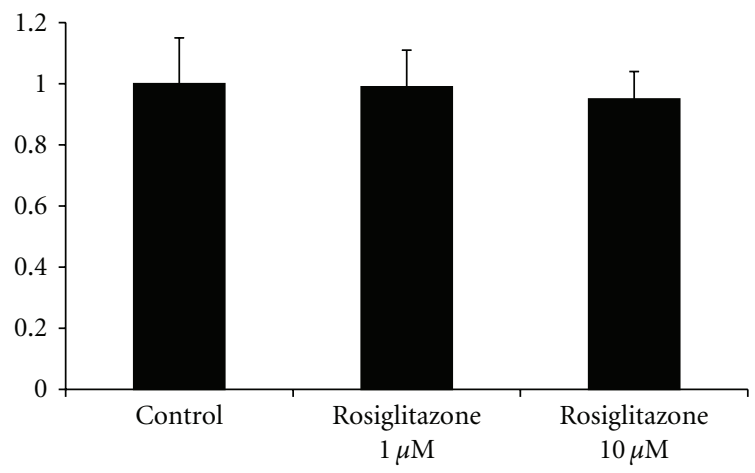

FIGURE 3: Effect of rosiglitazone on mesothelial cell viability and proliferation. MC were stimulated with rosiglitazone in the given concentrations for 48 hours, and then a MTT test was performed as described in the Methods section. Results are described in relation to the control.

type 2 diabetic patients receiving peritoneal dialysis [23]. In the present study, we could demonstrate that TZD are able to reduce the constitutive MCP-1 release in MC by PPAR- $\gamma$ stimulation. Furthermore, rosiglitazone was able to attenuate enhanced MCP-1 secretion resulting from a stimulation with the proinflammatory cytokine TNF $\alpha$. Peng et al. found a decrease in high glucose concentration-induced mesothelial production of TGF $\beta$, collagen I, and fibronection secretion after treatment with troglitazone [14]. Some in vivo animal model studies point toward positive TZD effects on the peritoneal membrane in PD or peritoneal inflammation: Yao et al. found maintained peritoneal morphology and increased ultrafiltration after intraperitoneal administration of rosiglitazone in comparison to commercial PD solution alone [24]. Sandoval et al. described a reduction in the accumulation of AGEs as well as reduced fibrosis and angiogenesis resulting in an improved peritoneal function [25]. In accordance with our findings, Hornung et al. were able to demonstrate that the intraperitoneal administration of ciglitazone was able to significantly reduce the number of invading peritoneal macrophages following a thioglycollateinduced peritoneal inflammation [26]. PPAR- $\gamma$ stimulation in $\mathrm{MC}$ may be a promising possibility in the attempt to minimize long-term PD complications. However, potential negative effects of the TZD (the only commercially available PPAR- $\gamma$ activators at present) such as their ability to cause edema and their negative cardiovascular risk profile [27] should be considered critically.

\section{Conclusions}

PPAR- $\gamma 1$ protein is expressed on human peritoneal MC. Its activation via rosiglitazone decreases the mesothelial release and mRNA expression of MCP-1 and attenuates the TNF $\alpha$-induced enhancement in MCP-1 release in these cells. Therefore, the PPAR $-\gamma 1$ receptor may be a therapeutic target to ameliorate peritoneal inflammation and long-time 


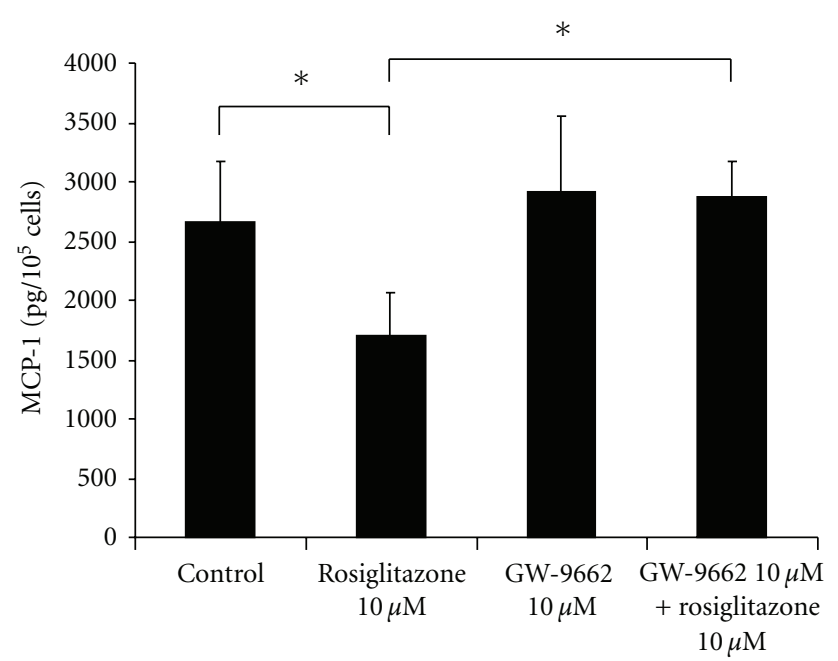

(a)

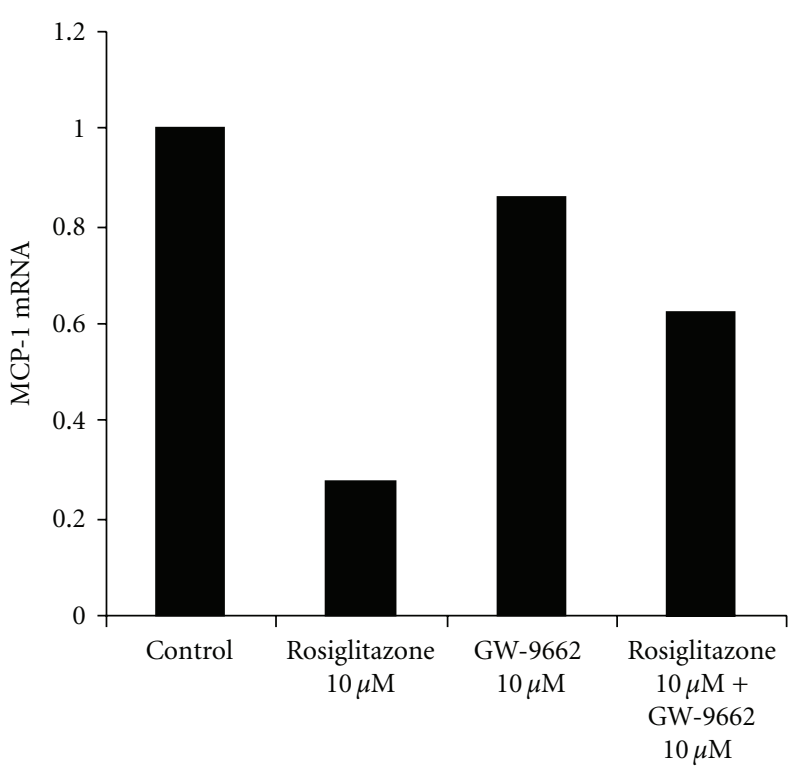

(b)

FIGURE 4: (a) PPAR- $\gamma$-dependency of the rosiglitazone effect on mesothelial MCP-1 release. MC were preincubated with GW-9662 $10 \mu \mathrm{M}$ for 24 hours (or with control media) and then incubated with the given conditions for 8 hours. Cell supernatants were examined by ELISA. *indicates a $P$ value $<0.05(n=5)$. (b) PPAR- $\gamma$-dependency of the rosiglitazone effect on mesothelial MCP-1 mRNA expression. MC were preincubated with GW-9662 $10 \mu \mathrm{M}$ for 24 hours (or with control media) and then incubated with the given conditions for 8 hours. Total RNA was extracted and examined by RT-PCR. The figure shows a representative experiment out of three independent ones.

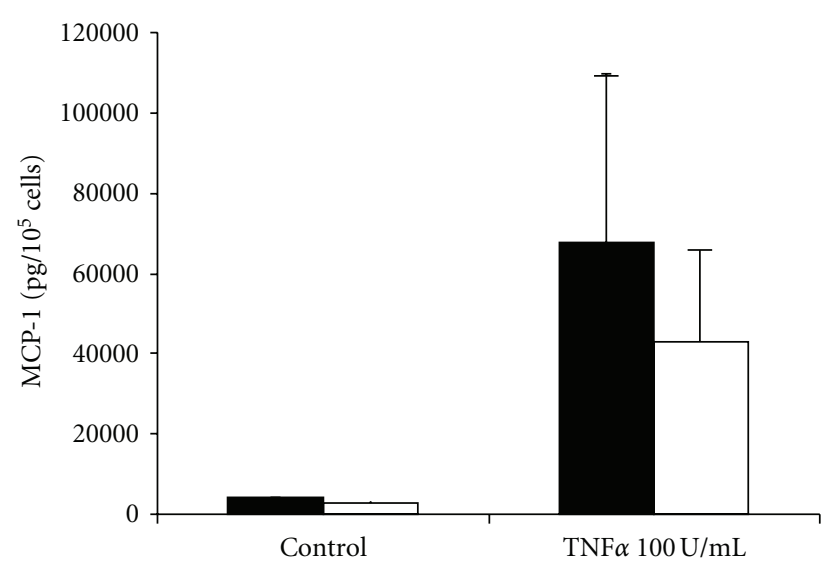

Figure 5: Effect of rosiglitazone on TNF $\alpha$-induced enhancement of mesothelial MCP-1 secretion. MC were preincubated with rosiglitazone $10 \mu \mathrm{M}$ (white bars) or with control medium (black bars) for 24 hours. Afterwards, the culture media was replaced with media containing rosiglitazone $10 \mu \mathrm{M}$ (white bars) or not (black bars) to the given conditions. After an incubation time of 8 hours, culture supernatants were analysed by ELISA $(n=3)$.

survival of the peritoneal membrane in PD. However, potential negative systemic effects of the TZD have to be considered critically.

\section{Acknowledgment}

This work was supported by a grant from the Else-KrönerFreseniusstiftung to M. Sauter and T. Sitter.

\section{References}

[1] N. Topley, T. Liberek, A. Davenport, F. K. Li, H. Fear, and J. D. Williams, "Activation of inflammation and leukocyte recruitment into the peritoneal cavity," Kidney International, Supplement, vol. 50, no. 56, pp. S17-S21, 1996.

[2] N. Topley, "The cytokine network controlling peritoneal inflammation," Peritoneal Dialysis International, vol. 15, no. 7, pp. S35-S40, 1995. 
[3] A. Jorres, K. Ludat, K. Sander et al., "The peritoneal fibroblast and the control of peritoneal inflammation," Kidney International, Supplement, vol. 50, no. 56, pp. S22-S27, 1996.

[4] S. M. Krane and M. B. Goldring, "Potential role for interleukin-1 in fibrosis associated with chronic ambulatory peritoneal dialysis," Blood Purification, vol. 6, no. 3, pp. 173-177, 1988.

[5] C. Knouff and J. Auwerx, "Peroxisome proliferator-activated receptor- $\gamma$ calls for activation in moderation: lessons from genetics and pharmacology," Endocrine Reviews, vol. 25, no. 6, pp. 899-918, 2004.

[6] M. Li, G. Pascual, and C. K. Glass, "Peroxisome proliferatoractivated receptor $\gamma$-dependent repression of the inducible nitric oxide synthase gene," Molecular and Cellular Biology, vol. 20, no. 13, pp. 4699-4707, 2000.

[7] Y. Rival, N. Benéteau, V. Chapuis et al., "Cardiovascular drugs inhibit MMP-9 activity from human THP-1 macrophages," DNA and Cell Biology, vol. 23, no. 5, pp. 283-292, 2004.

[8] A. Momoi, K. Murao, H. Imachi et al., "Inhibition of monocyte chemoattractant protein-1 expression in cytokine-treated human lung epithelial cells by thiazolidinedione," Chest, vol. 120, no. 4, pp. 1293-1300, 2001.

[9] M. Y. Ohta, Y. Nagai, T. Takamura, E. Nohara, and K. I. Kobayashi, "Inhibitory effect of troglitazone on TNF- $\alpha$-induced expression of monocyte chemoattractant protein-1 (MCP-1) in human endothelial cells," Diabetes Research and Clinical Practice, vol. 48, no. 3, pp. 171-176, 2000.

[10] G. Gruden, G. Setti, A. Hayward et al., "Mechanical stretch induces monocyte chemoattractant activity via an NF- $\kappa \mathrm{B}-$ dependent monocyte chemoattractant protein-1-mediated pathway in human mesangial cells: inhibition by rosiglitazone," Journal of the American Society of Nephrology, vol. 16, no. 3, pp. 688-696, 2005.

[11] V. W. M. van Hinsbergh, T. Kooistra, M. A. Scheffer, J. H. van Bockel, and G. N. P. van Muijen, "Characterization and fibrinolytic properties of human omental tissue mesothelial cells. Comparison with endothelial cells," Blood, vol. 75, no. 7, pp. 1490-1497, 1990.

[12] L. Fink, W. Seeger, L. Ermert et al., "Real-time quantitative RTPCR after laser-assisted cell picking," Nature Medicine, vol. 4, no. 11, pp. 1329-1333, 1998.

[13] S. H. Park, S. Y. Choi, M. H. Kim et al., "The TGF- $\beta$-induced gene product, $\beta$ ig-h3: its biological implications in peritoneal dialysis," Nephrology Dialysis Transplantation, vol. 23, no. 1, pp. 126-135, 2008.

[14] Y. Peng, H. Liu, F. Liu, Y. Liu, J. Li, and X. Chen, “Troglitazone inhibits synthesis of transforming growth factor- $\beta 1$ and reduces matrix production in human peritoneal mesothelial cells," Nephrology, vol. 11, no. 6, pp. 516-523, 2006.

[15] M. Sauter, C. D. Cohen, M. Wörnle, T. Mussack, R. Ladurner, and T. Sitter, "ACE inhibitor and AT1-receptor blocker attenuate the production of VEGF in mesothelial cells," Peritoneal Dialysis International, vol. 27, no. 2, pp. 167-172, 2007.

[16] M. Sach, K. Bauermeister, J. A. Burger et al., "Inverse MCP1/IL-8 ratio in effluents of CAPD patients with peritonitis and in isolated cultured human peritoneal macrophages," $\mathrm{Ne}$ phrology Dialysis Transplantation, vol. 12, no. 2, pp. 315-320, 1997.

[17] A. R. Malik, M. A. Little, M. Henriksson, F. W. K. Tam, and E. A. Brown, "Peritonitis, peritoneal inflammation and membrane permeability: a longitudinal study of dialysate and serum MCP-1 in stable patients on peritoneal dialysis," Journal of Nephrology, vol. 20, no. 3, pp. 340-349, 2007.
[18] T. Y. H. Wong, A. O. Phillips, J. Witowski, and N. Topley, "Glucose-mediated induction of TGF- $\beta 1$ and MCP- 1 in mesothelial cells in vitro is osmolality and polyol pathway dependent," Kidney International, vol. 63, no. 4, pp. 1404-1416, 2003.

[19] N. Jonjic, G. Peri, S. Bernasconi et al., "Expression of adhesion molecules and chemotactic cytokines in cultured human mesothelial cells," Journal of Experimental Medicine, vol. 176, no. 4, pp. 1165-1174, 1992.

[20] A. Chawta, J. J. Repa, R. M. Evans, and D. J. Mangelsdorf, "Nuclear receptors and lipid physiology: opening the x-files," Science, vol. 294, no. 5548, pp. 1866-1870, 2001.

[21] M. Lehrke and M. A. Lazar, "The many faces of PPAR $y$," Cell, vol. 123, no. 6, pp. 993-999, 2005.

[22] S. H. Lin, Y. F. Lin, S. W. Kuo, Y. J. Hsu, and Y. J. Hung, "Rosiglitazone improves glucose metabolism in nondiabetic uremic patients on CAPD," American Journal of Kidney Diseases, vol. 42, no. 4, pp. 774-780, 2003.

[23] T. Y. H. Wong, C. C. Szeto, K. M. Chow, C. B. Leung, C. W. K. Lam, and P. K. T. Li, "Rosiglitazone reduces insulin requirement and C-reactive protein levels in type 2 diabetic patients receiving peritoneal dialysis," American Journal of Kidney Diseases, vol. 46, no. 4, pp. 713-719, 2005.

[24] Q. Yao, K. Pawlaczyk, E. R. Ayala et al., "Peroxisome proliferator-activated receptor- $\gamma$ agonists diminish peritoneal functional and morphological changes induced by bioincompatible peritoneal dialysis solution," Blood Purification, vol. 24, no. 5-6, pp. 575-582, 2006.

[25] P. Sandoval, J. Loureiro, G. González-Mateo et al., "PPAR- $\gamma$ agonist rosiglitazone protects peritoneal membrane from dialysis fluid-induced damage," Laboratory Investigation, vol. 90, no. 10, pp. 1517-1532, 2010.

[26] D. Hornung, V. A. Chao, J.-L. Vigne, D. Wallwiener, and R. N. Taylor, "Thiazolidinedione inhibition of peritoneal inflammation," Gynecologic and Obstetric Investigation, vol. 55, no. 1, pp. 20-24, 2003.

[27] S. E. Nissen and K. Wolski, "Effect of rosiglitazone on the risk of myocardial infarction and death from cardiovascular causes," The New England Journal of Medicine, vol. 356, no. 24, pp. 2457-2471, 2007. 


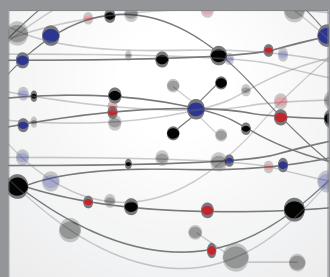

The Scientific World Journal
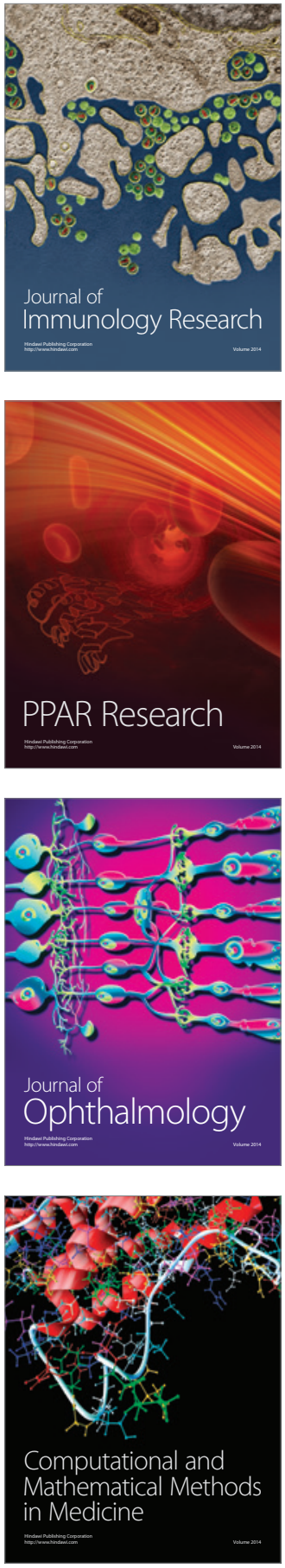

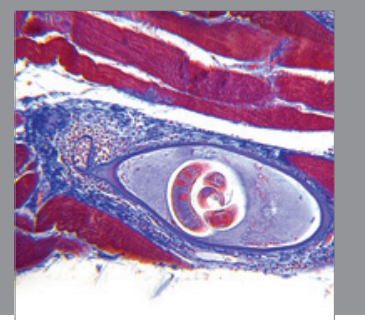

Gastroenterology

Research and Practice
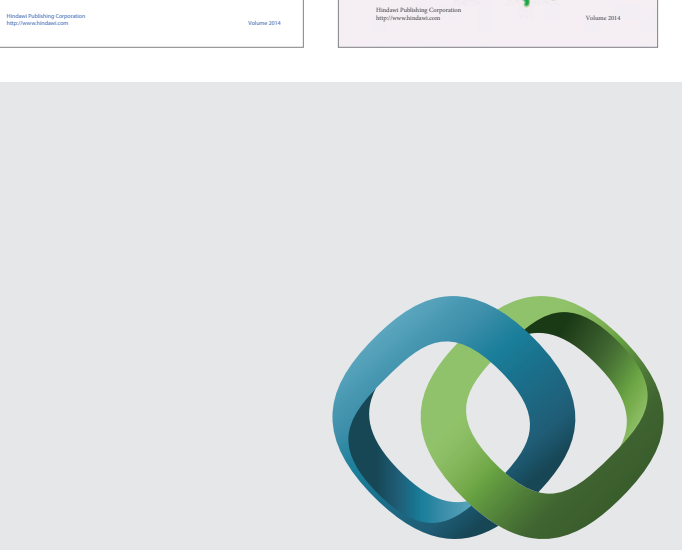

\section{Hindawi}

Submit your manuscripts at

http://www.hindawi.com
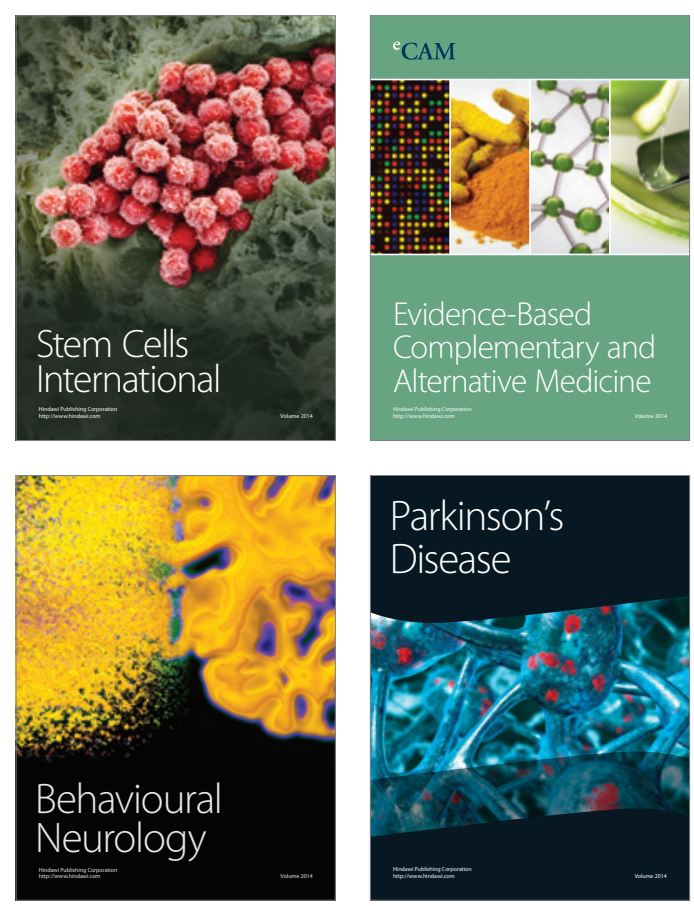

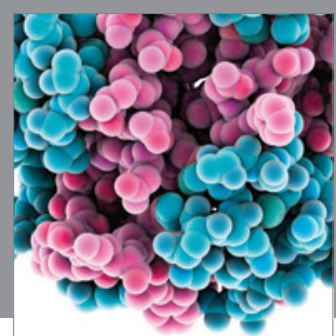

Journal of
Diabetes Research

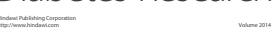

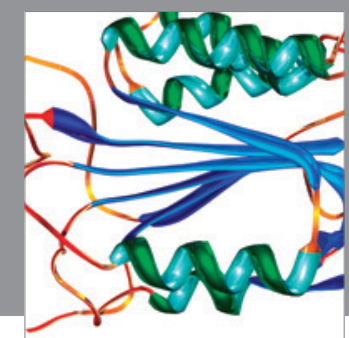

Disease Markers
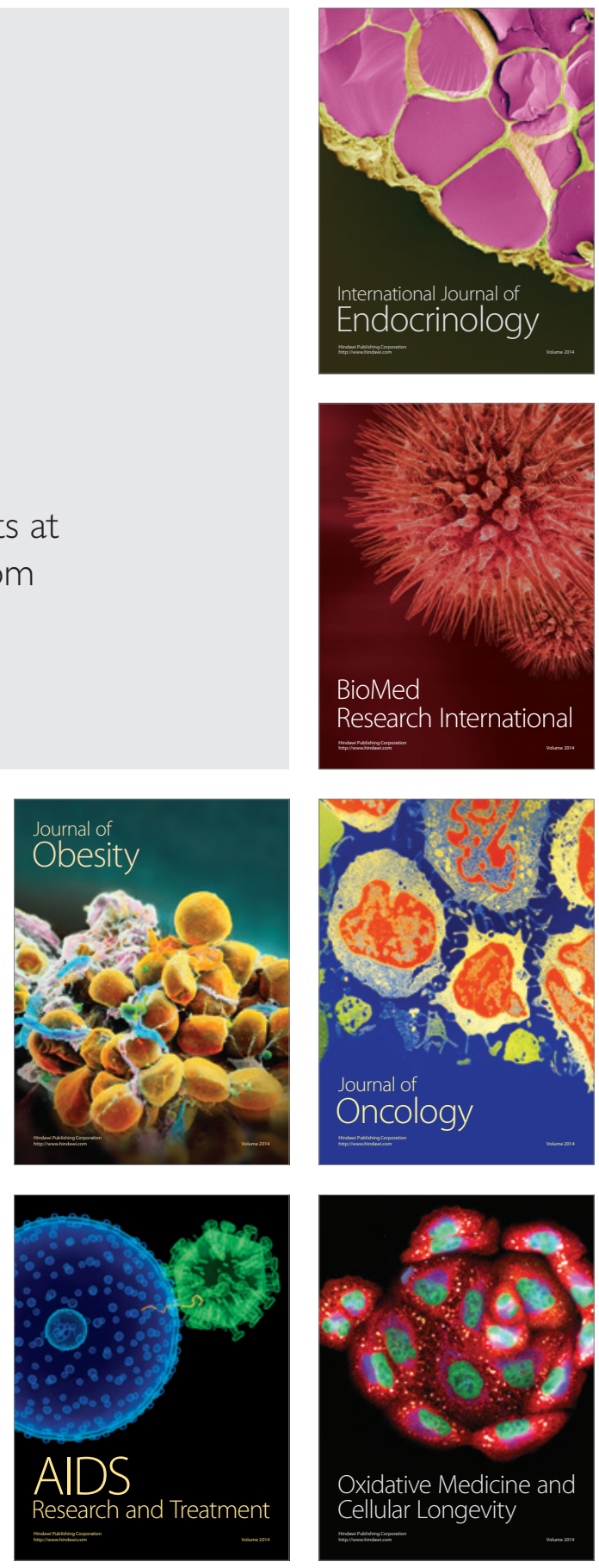